\title{
The Description of Needs Analysis of Learning Tools Using A PBL (Problem Based Learning) Model to Improve Mathematical Problems Solving
}

\author{
Samsi Suryanjani ${ }^{1}$, Riyadi $^{2}$, and Budi Usodo ${ }^{3}$ \\ \{suryanjanisamsi68@gmail.com ${ }^{1}$,riyadifkipuns@gmail.com ${ }^{2}$, budi_usodo@yahoo.com ${ }^{3}$ \} \\ ${ }^{1,2,3}$ Universitas Sebelas Maret, Surakarta, Indonesia
}

\begin{abstract}
This preliminary research discusses the needs of learning tools in State Elementary School 1 Girimarto, Wonogiri Regency. The learning tools are the supplementary teaching media for teacher. One of an appropriate models chosen in mathematical problems solving is the Problem Based Learning model. This study focuses on field studies and literature studies. The study aims to to; 1) find out the teachers' needs for appropriate learning tools, 2) find out the teachers' response toward the learning tools used in State Elementary School 1 Girimarto, 3) analyze the implementation of learning Mathematics in State Elementary School 1 Girimarto. This descriptive research uses cluster sampling technique to collect the data. The subjects were high school students and 3 teachers of grade IV, V, and VI at State Elementary School 1 Girimarto. The data was obtained by using questionnaires and students' need analysis. The data was analyzed qualitatively through coding, tabulating data, analyzing qualitatively, interpreting the results of the analysis according to the problems and research questions, and concluding. The conclusion show the need to develop learning tools with Problem Based Learning models to improve the quality of mathematics learning in problem solving.
\end{abstract}

Keywords: learning tools, problem based learning, problem solving

\section{INTRODUCTION}

Based on the results of daily tests on problem solving in the form of an essay in Girimartosub-district, the students' minimum level of the learning mastery was less than 50\%. This less-innovative mathematical learning must be followed up by improving the learning tools. Sanjaya argues that a tool is a number of materials, tools, media, instructions and guidelines that will be used to achieve the learning goals [1]. Batoq et.al. argue that the tools used in the learning process are called learning tools in the form of a number of materials, media, tools, instructions or guidelines that will be used in the process of learning activities [2]. Simanungkalit argues that the development of learning tools must be adjusted to the level of students' knowledge and experience[3]. Besides, the development of learning tools must also be adapted to the current curriculum. To develop learning tools, references can be obtained from a variety of sources, either in the form of experience or knowledge, or extracting information 
from expert sources as well as peer sources and references can also be obtained from books, mass media, the internet, and so on.

Susanti et.al. argue that out of the innovation of a learning model innovations, the use of tools also contributes to the factors that affect students' mathematical abilities in the learning process to gain learning experience [4]. A good learning tool certainly applies a learning model that is appropriate to the material.

According to (Joyce \& Well in Rusman , 2012)[5] the learning model is a plan or a pattern that can be used by teachers to design a curriculum (long-term learning plan), develop learning materials and guide a learning process in the classroom or others. One innovative learning model to solve mathematical problems is PBL learning model or Problem Based Learning.

As the purpose of mathematics subject in schools emphasizes the problem solving ability and the application of mathematics so that the Problem Based Learning model needs to be applied in mathematics learning. According to Peter, et.al., Problem Based Learning is a learning method in which the learner faces a problem firstly, followed by a systematic and student-centered inquiry process [6]. From this problem, students are stimulated to analyze the problems based on the knowledge and new experience. Problem Based Learning is defined as hands and minds on the complex problems with many directions and solved in various ways $[7]$.

The characteristics of the Problem Based Learning model that students can make decisions about a framework [8]. The problems or challenges exist and must be solved by the students. The students are also designed the process to determine the problem solving. They are collaboratively responsible for accessing and managing information to solve problems. The evaluation process is carried out continuously. They regularly reflect on the activities that have been carried out. The final product of learning activities will be evaluated qualitatively. Then, learning situations are very tolerant of mistakes and changes.

Barrett and Moore argue that the main characteristic of Problem Based Learning is that problems are presented to the students at the beginning of the learning process after reflection of the curriculum [9]. Thomas argues that problem-based learning or Problem Based Learning is a learning approach that presents contextual problems that stimulate students to learn [10].

The strengths of Problem Based Learning are that it can make education in schools more relevant to life, especially with the real work-life [11]. It also can make the students skillfully accustom to the problem solving, which are useful for their future to face the real problems. Additionally, it can stimulate the development of the ability to think creatively and comprehensively, because students do a lot of mental processes by highlighting problems from various aspects in the learning process. The effects of Problem Based Learning are that the students have the inquiry skills, problem solving skills, and the ability to learn the role of adults [12]. In addition, the students are able to become independent learners.

Furthermore, the disadvantages of Problem Based Learning [13]. First of all, a Problembased learning cannot be applied to any subject matter. There is a part of the teacher playing an active role in presenting the material. Problem-based learning is more suitable for learning that demands certain abilities related to problem solving. Second, there will be difficulties in the distribution of tasks in a class that the students are from various different high levels. The weaknesses of learning outcomes from Problem Based Learning are that it takes a lot of time and cannot be used in a low level of classes. Also, not all students are skillful at inquiring [14].

The relevant research of Problem Based Learning conducted a reflection or positive benefits for pre-service primary school teachers in terms of learning [15]. The effectiveness of Problem Based Learning that is widely used as a teaching method [16]. Based on this background, it is 
necessary to develop a learning tool with the Problem Based Learning model to improve student learning outcomes in problem solving.

\section{METHOD}

This was a descriptive research. In this study, Cluster sampling was used as a sample. The subjects of the study were elementary school students of State Elementary School 1 Girimarto grade IV, V, and VI consisting of 87 students and 3 teachers of those grades. The data was collected by using questionnaires of teachers' and students' need analysis. The data was analyzed through four stages. The first step was coding data from the distribution of questionnaires. The second stage was data tabulation to know classes, characteristics, types and data frequency of data appear so that the data was easy to read, categorize, and analyze. The third stage was qualitative data analysis, which was analyzed by describing and linking the data and information related to the focus of research. The fourth stage is to make an interpretation of the results of the analysis in accordance with the problems and questions of the researcher and make conclusions.

\section{RESULT AND DISCUSSION}

The results of the teachers' need analysis found in the field based on the results of observations made by the teachers need a learning tool that emphasizes on one of the appropriate models in each learning

Table 1. The Questionnaire Analysis Result of Learning Tools' Needs in Mathematics Subjects for teachers of State Elementary School 1 Girimarto

\begin{tabular}{|c|c|c|c|}
\hline No & Question Analysis & Problems' Identification & Iidentification \\
\hline 1 & $\begin{array}{l}100 \% \text { teachers know and } \\
\text { understand } 2013 \text { curriculum } \\
\text { applied in a high level class. }\end{array}$ & $\begin{array}{l}\text { The implementation of } 2013 \\
\text { curriculum used in schools }\end{array}$ & $\begin{array}{l}\text { The teachers apply } 2013 \\
\text { curriculum to teach. }\end{array}$ \\
\hline 2 & $\begin{array}{l}100 \% \text { teachers state that the } \\
\text { students' minimum level of } \\
\text { the learning mastery } \\
\text { determined by the school is } \\
70 \text {. }\end{array}$ & $\begin{array}{l}\text { Teachers know how to } \\
\text { implement the students' } \\
\text { minimum level of the learning } \\
\text { mastery with high standard in } \\
\text { the school. }\end{array}$ & $\begin{array}{l}\text { Teachers set high } \\
\text { standard of the students' } \\
\text { minimum level of the } \\
\text { learning mastery. }\end{array}$ \\
\hline 3 & $\begin{array}{l}100 \% \text { teachers argue that } \\
\text { students who fulfill the } \\
\text { students' minimum level of } \\
\text { the learning mastery are about } \\
25 \% \text { students. }\end{array}$ & $\begin{array}{l}\text { Teachers realize the low level } \\
\text { of the students' learning } \\
\text { mastery. }\end{array}$ & $\begin{array}{l}\text { The low level of the } \\
\text { students' learning } \\
\text { mastery. }\end{array}$ \\
\hline 4 & $\begin{array}{l}100 \% \text { teachers argue that they } \\
\text { have already implemented the } \\
\text { direct learning dominated by } \\
\text { lecturing. }\end{array}$ & $\begin{array}{l}\text { Teachers often apply the direct } \\
\text { learning. }\end{array}$ & A boring learning model. \\
\hline 5 & $\begin{array}{l}66,66 \% \text { teachers argue that } \\
\text { the used learning model is } \\
\text { dislike by students, that is a } \\
\text { direct learning. }\end{array}$ & $\begin{array}{l}\text { Teachers' opinion whether } \\
\text { students like the applied model } \\
\text { in learning. }\end{array}$ & $\begin{array}{l}\text { Teachers' awareness of } \\
\text { an applied model that } \\
\text { students do not like. }\end{array}$ \\
\hline 6 & $\begin{array}{l}66,66 \% \text { teachers argue that } \\
\text { lack of the implementation of } \\
\text { an innovative learning model. }\end{array}$ & $\begin{array}{l}\text { Lack of the implementation of } \\
\text { an innovative learning model. }\end{array}$ & $\begin{array}{l}\text { Low level of the } \\
\text { implementation of an } \\
\text { innovative learning } \\
\text { model. }\end{array}$ \\
\hline
\end{tabular}



model applied without understanding its steps. applied media has not motivated students maximally in learning.

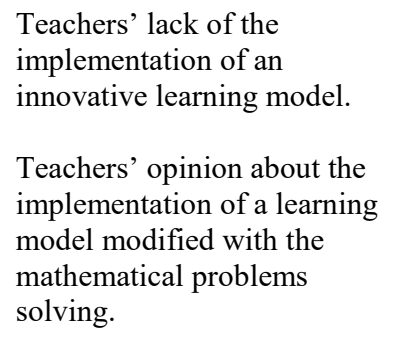

\author{
Teachers' low level of \\ the implementation of an \\ innovative learning \\ model. \\ The implementation of a \\ learning model modified \\ with the mathematical \\ problems solving is not \\ used maximally to \\ motivate students.
}

Regarding to the results of the needs analysis, the teachers of State Elementary School 1 Girimartorealized that the learning outcomes of students in solving mathematical problems were still low. It was because in teaching and learning process the teachers still used direct learning dominated by lecturing. In relation to these facts, to improve students' learning outcomes, the teachers attempted to apply innovative models; one of which was the PBL model on the learning tools to attract students' interest and motivation. The application of the PBL model on learning tools was expected to improve students' learning outcomes in solving mathematical problems [17].

Table 2. The Questionnaire Analysis Result of Learning Tools Needs with the Problem Based Learning Model in Mathematics Subjects for Students of State Elementary School 1Girimarto

\begin{tabular}{|c|c|}
\hline No & $\begin{array}{l}\text { Statements' Analysis } \\
\end{array}$ \\
\hline 1 & $80 \%$ students respond that mathematic is a difficult subject. \\
\hline 2 & $74 \%$ students respond that they get below standard for their mathematic subject. \\
\hline 3 & $69 \%$ students respond that mathematical learning activities are often use a direct learning. \\
\hline 4 & $64 \%$ students respond that the applied model is less motivated in problem solving. \\
\hline 5 & $63 \%$ students respond that they want an innovative and easily-understood learning model. \\
\hline 6 & $66 \%$ students respond that problem solving tasks are answered directly without a process. \\
\hline 7 & $\begin{array}{l}57 \% \text { students respond that the learning applied by teachers is not clear in mathematic } \\
\text { problem solving activities. }\end{array}$ \\
\hline 8 & $\begin{array}{l}91 \% \text { students support the implementation of PBL model as teachers' media to teach } \\
\text { mathematics subject. }\end{array}$ \\
\hline
\end{tabular}

The result of questionnaires of students' needs in State Elementary School 1 Girimarto showed that the students supported the implementation of the PBL model as the teacher's learning tools on mathematics subjects (91\%). The writer had confidence that if the PBL model was applied, the learning process would not be boring. More than $50 \%$ of students could solve problems with problems solving activities. Based on the findings, the writer found the need to improve the quality of learning Mathematics at State Elementary School 1 Girimarto. One thing that needs to be done was to improve the quality of the teacher's skills to design and carry out Mathematical learning activities that could increase students' interest and motivation so that the learning outcomes were as expected. 


\section{CONCLUSION}

Learning tools with Problem Based Learning models are important to be developed to improve students' ability in problems solving. Learning tools are a guideline for teachers when conducting teaching and learning process in the class. Developing learning tools must apply innovative learning models in accordance with the material being studied. An innovative model will trigger students to actively join the discussion with their groups to solve the questions discussed in the discussion group. Innovative learning models have many types and variations, but not all innovative learning models can be used effectively in certain aspects of learning. Problem Based Learning model is a learning model focusing on student-centered. This is strongly needed in the implementation of learning in order to attract students' attention. Student active involvement is an essential part of a teaching and learning activity.

\section{REFERENCES}

[1] W. Sanjaya. Perencanaan dan Desain Sistem Pembelajaran. Jakarta: Kencana. 2010.

[2] I. Batoq, I. Susila, and T. Rijanto. "Pengembangan Perangkat Pembelajaran Model Kooperatif Tipe Jigsaw Berbasis Kurikulum 2013 pada Mata Pelajaran Sistem Pendinginan Bahan Bakar dan Pelumas di SMKN 3 Sendawar". Biomass Chem Eng, 2015.

[3] R. H. Simanungkalit. "Pengembangan Perangkat Pembelajaran untuk Meningkatkan Kemampuan Pemecahan Masalah Matematis Siswa SMP Negeri 12 Pematangsiantar". MUST: Journal of Mathematics Education, Science and Technology, Vol. 1, No. 1, pp. 39, 2018.

[4] S. Susanti, E. Musdi, and, H. Syarifuddin. "Pengembangan Perangkat Pembelajaran Matematika Berbasis Penemuan Terbimbing untuk Meningkatkan Kemampuan Pemecahan Masalah Matematis Materi Statistika". JNPM (Jurnal Nasional Pendidikan Matematika), Vol. 1, No. 2, pp. 305-319, 2019.

[5] Rusman. Model Model Pembelajaran Mengembangkan Profesional Guru. Jakarta: PT Raja Grafindo Persada, 2012.

[6] S. Peter, M. Steward, and W. Graham. Problem Based Learning Case Studies Experience and Practice. London: British Library Cataloguing in Publication Data, 2012.

[7] F. Liz. Bringing Problem Based Learning into the Science Classroom. USA: McNaughton and Gunn Inc, 2010.

[8] M. Abdul and R. Chaerul. Pendekatan Ilmiah dalam Implementasi Kurikulum 2013. Bandung: Remaja Rosdakarya, 2015.

[9] B. Terry and M. Sarah. New Approaches to Problem Based Learning Revitalising Your Practice in Higher Education. France: Taylor \& Francis, 2010.

[10] T. Thomas. Teaching is an Art Maximize Your Teaching. Sleman: Deepublish, 2012.

[11] N. Abuddin. Perspektif Islam Tentang Strategi Pembelajaran. Jakarta: Kencana Prenadamedia Group, 2014.

[12] S. Agus. Cooperative Learning Teori dan Aplikasi Paikem. Yogyakarta: Pustaka Pelajar, 2009.

[13] S. Aris. Model Pembelajaran Inovatif dalam Kurikulum 2013. Yogyakarta: Ar Ruzz Media, 2014.

[14] T. Muhammad and M. Arif. Belajar dan Pembelajaran. Yogyakarta: ArRuzz Media, 2011. 
[15] N. B Zeliha. "The Problem-Based Learning Process: Reflections of Pre-Service Elementary School Teachers". Educational Research and Reviews, Vol. 12, No. 4, pp. 177-188, 2017.

[16] A. J. Charlton-Perez. "Problem-Based Learning Approaches in Meteorology". Journal of Geoscience Education, Vol. 6, No. 1, pp. 12-19, 2013.

[17] K. Saddhono and M. Rohmadi, "A Sociolinguistics Study on the Use of the Javanese Language in the Learning Process in Primary Schools in Surakarta, Central Java, Indonesia." Int. Edu. Stu., vol. 7 no.6 pp 25-30, 2014 